\title{
Seed Germination and Seedling Growth of Alnus maritima from Its Three Disjunct Populations
}

\author{
James A. Schrader and William R. Graves \\ Department of Horticulture, Iowa State University, Ames, IA 50011-1100
}

\begin{abstract}
AdDITIONAL INDEX wORDs. seaside alder, germination percentage, germination value, genotypic variation, morphology, provenance, threatened and endangered species

Abstract. Genotypic variation and horticultural potential of Alnus maritima [Marsh.] Nutt. (seaside alder), a large shrub or small tree found naturally in only three small, disjunct populations, have not been studied. We examined effects of population of origin and environment on seed germination and growth and morphology of seedlings. The first experiment showed that 6 weeks of cold stratification optimized germination of half-sibling seeds from Oklahoma at 73.2\%. When this treatment was applied to multiple groups of half-siblings from all populations in a second experiment, seeds from Oklahoma had a higher germination percentage (55.0\%) than seeds from Georgia (31.4\%) and the Delmarva Peninsula $(\mathbf{1 4 . 7 \%})$. In a third experiment, morphology and growth of multiple groups of half-siblings from all three populations were compared in one environment. Leaves of seedlings from Oklahoma were longer $(12.8 \mathrm{~cm})$ and more narrow $(2.15$ length to width ratio) than leaves of seedlings from Georgia $(12.0 \mathrm{~cm}$ long; ratio $=1.76)$ and the Delmarva Peninsula $(11.6 \mathrm{~cm}$ long; ratio $=1.86)$. Seedlings from Oklahoma and Georgia accumulated dry weight at higher rates $\left(181\right.$ and $160 \mathrm{mg}^{-1}$,

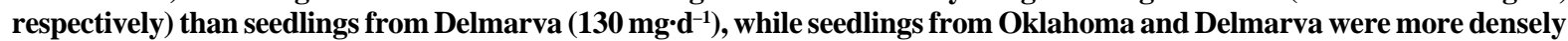
foliated (0.72 and 0.64 leaves and lateral shoots per centimeter of primary stem, respectively) than those from Georgia $(0.46$ per $\mathrm{cm})$. These differences indicate genetic divergence among the three disjunct populations and the potential to exploit genetic variation to select horticulturally superior $A$. maritima for use in managed landscapes.
\end{abstract}

Alnus maritima (seaside alder) is a rare, North American species indigenous to only three small, disjunct areas separated by $\geq 1000 \mathrm{~km}$. Alnus maritima occurs naturally in two counties in south-central Oklahoma, one county in northwestern Georgia, and six counties on the Delmarva Peninsula (Eastern Shore of Maryland and southern Delaware) in soils often saturated with fresh water. The presence of this species in Oklahoma and the Delmarva Peninsula has been recognized for many years (Furlow, 1979; Stibolt, 1981), while the population in Georgia was discovered in 1997 (B. Dickman, personal communication). Because of its restricted range, A. maritima is considered rare or imperiled both globally and at the state level in the Natural Heritage Inventories of Oklahoma and Maryland. The need to conserve $A$. maritima is one reason why its reproductive and population biology should be studied.

Its aesthetic and physiological attributes suggest $A$. maritima may merit use in managed landscapes. In the wild, A. maritima grows to $10 \mathrm{~m}$ tall with several trunks $\leq 15 \mathrm{~cm}$ in diameter (Furlow, 1979). Particularly appealing are its glossy foliage, which is darker green than that of all other North American alders, and pendulous staminate catkins that are yellow in late summer and early autumn (Furlow, 1979; Mazzeo, 1986). Alnus maritima may also be unusually well adapted to poor edaphic conditions. Although they grow only in wet soils in nature, plants of $A$. maritima respond more favorably to drought than plants of the more commonly used Alnus glutinosa [L.] Gaertn. (black alder) (Hennessey et al., 1985). The capacity of A. maritima to associate with nitrogen-fixing bacteria (Furlow, 1979) also suggests that plants would perform relatively well under conditions that lead to

Received for publication 1 June 1999. Accepted for publication 30 Sept. 1999. Iowa Agriculture and Home Economics Experiment Station journal paper J18349, Project 3229, and supported by the Hatch Act and state of Iowa funds. This project was supported in part by grants from the J. Frank Schmidt Family Charitable Trust and the Landscape Plant Development Center. We wish to express appreciation to Lou Anella, Brian Dickman, Nancy Stewart, and Virginia Stibolt for assistance with seed collection. The cost of publishing this paper was defrayed in part by the payment of page charges. Under postal regulations, this paper therefore must be hereby marked advertisement solely to indicate this fact. physiological stresses in many other woody taxa (Benson and Sylvester, 1993).

Genetic differences among and within the three disjunct populations of A. maritima might permit selection of individuals with superior horticultural traits. Efforts to select plants should be facilitated by knowing the extent of variation and whether differences are related to geographic origin. For example, selection efforts could focus on only one or two of the populations if plants in them consistently exhibit superior growth rates or foliar qualities. Data on sexual reproductive capacity would aid plant propagators and would help in judging the potential for this species to be invasive outside of its natural habitat.

The overall objective of this research was to describe environmental and population effects on seed germination and seedling growth of A. maritima. Embryo dormancy is the major hindrance to germination of viable seeds of other alders, but moist stratification at $\approx 5^{\circ} \mathrm{C}$ improves germination (Bewley and Black, 1994). The optimum stratification period for seeds of woody plants varies among species (Dirr and Heuser, 1987) but is not known for A. maritima. We used seeds from a single plant in Oklahoma to examine effects of duration of cold stratification. A second experiment included seeds from multiple plants from each population to assess genetic variation in seed germinability, and a third experiment examined growth and development of seedlings. The three populations of A. maritima were found to vary in their reproductive biology, growth, and morphology in ways that may prove significant to horticulturists.

\section{Materials and Methods}

\section{Seed germination}

GERMPLASM. Seeds were acquired by collecting newly matured strobili during November (Oklahoma) and December (Delmarva and Georgia) 1997. In Oklahoma, fruits were collected from plants along the Blue River (latitude $34^{\circ} 19^{\prime} 40^{\prime \prime} \mathrm{N}$; longitude $96^{\circ} 35^{\prime} 30^{\prime \prime} \mathrm{W}$ ) and along Pennington Creek (latitude $34^{\circ} 19^{\prime} 20^{\prime \prime} \mathrm{N}$; longitude $96^{\circ} 42^{\prime} 20^{\prime \prime} \mathrm{W}$ ) in Johnston County. On the 
Delmarva Peninsula, fruits were collected from plants along Marshyhope Creek (latitude 38 37' 50'N ; longitude 75 49'0' W). Plants sampled in Georgia were located in and around Drummond Swamp (latitude $34^{\circ} 08^{\prime} 0$ '” $\mathrm{N}$; longitude $84^{\circ} 57^{\prime} 15^{\prime \prime} \mathrm{W}$ ) in Bartow County. Strobili were air dried under ambient conditions $\left[\approx 22^{\circ} \mathrm{C}\right.$ and $\approx 45 \%$ relative humidity $(\mathrm{RH})]$ for 1 week, and seeds were stored at $4{ }^{\circ} \mathrm{C}$ until use ( $<5$ months) in sealed, plastic containers. Seed moisture content during storage was $10.1 \%$ (International Seed Testing Association, 1985).

ExPERIMENTAL UNITS. Fifty, half-sibling seeds held between two pieces of $90-\mathrm{mm}$-diameter filter paper within a $100 \times 15-\mathrm{mm}$, plastic petri plate constituted an experimental unit for both experiments. The 50 seeds in each unit were first weighed, then disinfested by submersal in $10 \%$ sodium hypochlorite for $2 \mathrm{~min}$, followed by two, 1-min rinses in distilled, deionized water (dd $\mathrm{H}_{2} \mathrm{O}$ ). Units assigned to no stratification received $2 \mathrm{~mL}$ dd $\mathrm{H}_{2} \mathrm{O}$ and were randomized in a growth chamber at $24 \pm 1{ }^{\circ} \mathrm{C}$ in the dark for $21 \mathrm{~d}$. Each stratified unit received $1 \mathrm{~mL}$ dd $\mathrm{H}_{2} \mathrm{O}$ and was held in the dark at $4 \pm 1{ }^{\circ} \mathrm{C}$ for various durations. All units were held in individual sealed, plastic bags to minimize evaporation. After

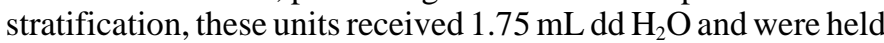
in the dark at $24 \pm 1{ }^{\circ} \mathrm{C}$. On day 3 and day 10 of germination, each stratified and nonstratified unit received $1.5 \mathrm{~mL}$ and $1.0 \mathrm{~mL}$ dd $\mathrm{H}_{2} \mathrm{O}$, respectively.

Measures of Germination. Emergence of a radicle, confirmed by viewing seeds at $15 \times$ magnification, constituted germination in both experiments. Seeds germinated in each unit were counted on days $3,4,6,8,10,12,14,16,18$, and 21 , and total germination percentage, mean daily germination, peak day, peak value, germination value (Czabator, 1962), and germination distribution were calculated. Mean daily germination is the total germination percentage divided by the number of days that the trial lasted and reflects the completeness of germination. Peak day is the day of the trial on which the greatest number of seeds germinated. Units with no germinated seeds after $21 \mathrm{~d}$ had no true peak day and were ascribed a 21 , the poorest score possible. Peak value is the cumulative germination percentage for each unit on its peak day, divided by the number of days to reach that percentage. Peak value and peak day reflect the rate of germination. Germination value reflects both germination rate and completeness and is the product of the mean daily germination and the peak value (Czabator, 1962). Germination distribution is the number of days over which radicle emergence took place in each unit and describes the uniformity of germination.
EFFects OF STRATIFiCATiOn DURATion. Experimental units with half-sibling seeds from one tree from Oklahoma were assigned to stratification treatments of $0,2,4,6,8,12$, and 16 weeks in a completely randomized design with 10 replications for each treatment. A tetrazolium test, a biochemical test that indicates living cells and tissues of seeds by the presence of red stain (International Seed Testing Association, 1985), was used to determine the viability of seeds from this source. The test was performed with eight replications of 50 seeds each.

VARIATION AMONG AND WITHIN POPUlations. Experimental units with half-sibling seeds from 27 trees (10 from Oklahoma, 10 from Delmarva, and seven from Georgia) were assigned to one of two treatments, a nonstratified control or a 6-week stratification period. This stratification period was chosen because it improved germination during the first experiment with one group of halfsibling seeds from Oklahoma. A randomized complete block design with nine blocks was used. Each block contained 27 units, one from each of the 27 maternal trees. One block was placed into stratification conditions each day for $6 \mathrm{~d}$. The remaining three blocks were assigned to the nonstratified control treatment. This design allowed the large number of units in the experiment to be monitored efficiently.

\section{Growth and morphology of seedlings}

INFLUENCE OF POPULATION AND SEED SOURCE. Stratified seeds from the 27 trees representing the three populations were germinated in petri plates as described. An experimental unit consisted of a $6.7-\mathrm{cm}$-diameter, square pot (height $=5.9 \mathrm{~cm}$; volume $=170$ $\mathrm{cm}^{3}$ ) containing germination mix (Strong Lite Horticulture Products, Seneca, Ill.) and two germinated seeds. A total of 324 experimental units was arranged in a randomized complete block design on a greenhouse bench from 11 May 1998 to 14 Sept. 1998, with 12 blocks that each contained one unit from each of the 27 seed sources. After 3 weeks, units were thinned to one seedling per pot. Plants were held under a 16-h photoperiod by using two 400-W, high-pressure sodium lamps to supplement natural irradiance. Environmental conditions were monitored twice each week with a model 1600 steady-state porometer (LI-COR, Lincoln, Nebr.) between 1200 and 1300 HR. The air averaged 23.1 ${ }^{\circ} \mathrm{C}$, mean $\mathrm{RH}$ was $47.2 \%$, and mean photosynthetically active radiation was $442 \mu \mathrm{mol} \cdot \mathrm{m}^{-2} \cdot \mathrm{s}^{-1}$. Units were irrigated with tap water every other day and received fertilizer solution of $11.0 \mathrm{~mm}$ $\mathrm{N}$ from a mixture of Peters Excel All-Purpose and Cal-Mag $(16.5 \mathrm{~N}-2.2 \mathrm{P}-13.5 \mathrm{~K})$ (Grace-Sierra Horticultural Products,

Table 1. Effects of stratification duration on germination of seeds from one seed source of the population of Alnus maritima from Oklahoma. Values are means of observations from 10 experimental units. Values in parentheses are means adjusted for effects of seed weight.

\begin{tabular}{|c|c|c|c|c|c|}
\hline \multirow{2}{*}{$\begin{array}{l}\text { Stratification } \\
\text { duration } \\
\text { (weeks) }\end{array}$} & \multicolumn{5}{|c|}{ Germination } \\
\hline & $\%$ & Value & $\begin{array}{l}\text { Peak } \\
\text { value }\end{array}$ & $\begin{array}{c}\text { Peak } \\
\text { day }\end{array}$ & $\begin{array}{l}\text { Distribution } \\
\text { (d) }\end{array}$ \\
\hline 0 & $61.0(67.0)$ & $14.6(23.4)$ & $4.9(6.2)$ & $10.6(10.8)$ & 13.8 \\
\hline 2 & $68.6(66.7)$ & $48.3(45.4)$ & $14.7(14.3)$ & $3.9(3.8)$ & 6.6 \\
\hline 4 & $71.0(68.5)$ & $61.4(57.7)$ & $18.0(17.5)$ & $3.2(3.1)$ & 5.6 \\
\hline 6 & $73.2(69.3)$ & $68.5(62.7)$ & $19.5(18.7)$ & $3.1(3.0)$ & 4.6 \\
\hline 8 & $63.2(64.6)$ & $47.4(49.4)$ & $15.9(16.1)$ & $3.3(3.3)$ & 4.2 \\
\hline 12 & $71.2(68.1)$ & $71.2(66.6)$ & $20.7(20.1)$ & $3.0(2.9)$ & 4.6 \\
\hline 16 & $59.8(63.9)$ & $45.0(51.1)$ & $15.5(16.4)$ & $3.7(3.8)$ & 6.2 \\
\hline \multicolumn{6}{|l|}{ Significance } \\
\hline Linear & $* *$ & $* * *$ & $* * *$ & $* * *$ & $* * *$ \\
\hline Quadratic & $* *$ & $* * *$ & $* * *$ & $* * *$ & $* * *$ \\
\hline
\end{tabular}

\footnotetext{
Significant at $P \leq 0.01$ or 0.001 , respectively
} 
Milpitas, Calif.) in tap water once a week. All irrigations were to container capacity. Six blocks were randomly selected and harvested after 12 weeks. The other six blocks were transplanted into $11.4-\mathrm{cm}$-diameter, round pots (height $=9.8 \mathrm{~cm}$; volume $=700$ $\mathrm{cm}^{3}$ ) with additional germination mix and grown six more weeks.

At both harvests, width perpendicular to the midvein at the widest point, length from the apex to the petiole, and length to width ratio of the newest fully expanded leaf of each plant were determined. Surface area of all leaves longer than $1 \mathrm{~cm}$ on each plant was measured by using a Model 3100 leaf area meter (LICOR). Leaf area ratio (Harper, 1977), dry leaf weight, and specific leaf weight (dry weight divided by surface area) also were determined. Expression of bullate (puckered or blistered) leaf surfaces was described by assigning each plant a rating of 1 or 2 when $<50 \%$ or $\geq 50 \%$ of the leaves were bullate, respectively.

Stem thickness at the cotyledonary node was measured with calipers. Plants were ascribed a stem curvature rating of 1 if the stem was uniformly upright or a 2 if the primary stem was distinctly curved or twisted. Overall angle of the primary stem was measured as the deviation from a line perpendicular with the upper plane of the pot, such that the smaller the angle, the more upright the growth habit. Length of the internode directly basipetal to the newest fully expanded leaf was measured, and shoot length was determined as the length of the primary stem from the cotyledonary node to the apex. The number of leaves plus axillary shoots longer than $1 \mathrm{~cm}$ was divided by shoot length to represent vegetative density of the primary shoot.

Dry weights of root and shoot systems and the ratio of root to shoot dry weight of each plant were determined. Net assimilation rate and relative growth rate for weeks 12 through 18 were calculated as described by Harper (1977). Simple growth rate was calculated by dividing the change in mean plant dry weight from week 12 to week 18 by the number of days of growth. Tissue dry weights were measured to the nearest $0.1 \mathrm{mg}$ by using an analytical balance after samples were dried in an oven at $60{ }^{\circ} \mathrm{C}$ for $3 \mathrm{~d}$.

\section{Statistical analysis}

Data for all experiments were analyzed by using the general linear models (GLM) procedure and the least significant difference (LSD) option of Statistical Analysis System software (SAS
Inst. Inc., 1988). Analysis of covariance was performed to assess how seed weight influenced germination. Least square means were calculated to adjust data on seed germination for the weight of the 50 seeds in each unit. Regression analysis was used to test linear and quadratic effects of stratification duration on seed germinability. A correlation procedure was used to examine if treatment effects on seeds from the various populations and sources were consistent.

\section{Results}

\section{Seed germination}

EFFECTS OF STRATIFICATION DURATION. Six weeks of stratification resulted in the highest germination percentage, while 12 weeks evoked the most pronounced increases in germination value and peak value (Table 1). Stratification for 12 and 8 weeks gave the lowest peak day and germination distribution, respectively. Analysis of covariance revealed that germination percentage $(P \leq 0.0001)$, germination value $(P \leq 0.0001)$, peak value $(P$ $=0.0007)$, and peak day $(P=0.0548)$ increased linearly with increasing seed weight, while germination distribution was not affected $(P=0.90)$. After adjusting data for effects of seed weight by calculating the least square means, treatments giving the highest responses within parameters remained the same (Table 1). Regression analysis of the unadjusted means showed that quadratic functions best represented germination percentage $(\mathrm{y}=$ $63.03+2.08$ [weeks] $-0.14\left[\right.$ weeks $\left.\left.^{2}\right] ; r^{2}=0.15\right)$, germination value $\left(\mathrm{y}=22.91+9.72\left[\right.\right.$ weeks] $-0.52\left[\right.$ weeks $\left.\left.^{2}\right] ; r^{2}=0.45\right)$, peak value $\left(\mathrm{y}=7.37+2.69[\right.$ weeks $]-0.14\left[\right.$ weeks $\left.\left.{ }^{2}\right] ; r^{2}=0.59\right)$, peak day $\left(\mathrm{y}=8.60-1.34\left[\right.\right.$ weeks] $+0.07\left[\right.$ weeks $\left.\left.^{2}\right] ; r^{2}=0.67\right)$, and germination distribution $\left(\mathrm{y}=12.02-1.80\left[\right.\right.$ weeks] $+0.09\left[\right.$ weeks $\left.^{2}\right] ; r^{2}=$ $0.54)$.

The tetrazolium test showed that $76.3 \%$ of seeds used in this experiment were viable. No embryo was found in $\approx 90 \%$ of the nonviable seeds. The remainder of nonviable seeds contained an embryo that showed no metabolic activity. Comparison of the results from the tetrazolium test with the unadjusted germination percentage obtained after 6 weeks of stratification $(73.2 \%)$ showed that the 6-week treatment led to $95.9 \%$ germination of viable seeds.

Table 2. Influence of stratification and population on germination of half-sibling seeds of Alnus maritima from Oklahoma (10 groups), Georgia (seven groups), and the Delmarva Peninsula (10 groups). Values for nonstratified and stratified seeds are means of three and six replications, respectively.

\begin{tabular}{|c|c|c|c|c|}
\hline \multirow{2}{*}{$\begin{array}{l}\text { Treatment } \\
\text { and } \\
\text { population }\end{array}$} & \multicolumn{4}{|c|}{ Germination } \\
\hline & $\%$ & Value & $\begin{array}{l}\text { Peak } \\
\text { value }\end{array}$ & $\begin{array}{c}\text { Peak } \\
\text { day }\end{array}$ \\
\hline \multicolumn{5}{|l|}{ Nonstratified } \\
\hline Oklahoma & $41.0 \mathrm{a}^{\mathrm{z}}$ & $7.4 \mathrm{a}$ & $3.2 \mathrm{a}$ & $10.2 \mathrm{~b}$ \\
\hline Georgia & $19.9 \mathrm{~b}$ & $2.2 \mathrm{~b}$ & $1.6 \mathrm{~b}$ & $10.5 \mathrm{~b}$ \\
\hline Delmarva & $10.8 \mathrm{~b}$ & $0.6 \mathrm{~b}$ & $0.7 \mathrm{~b}$ & $13.1 \mathrm{a}$ \\
\hline Treatment mean & $24.3 \mathrm{~A}^{\mathrm{y}}$ & $3.6 \mathrm{~B}$ & $1.9 \mathrm{~B}$ & $11.3 \mathrm{~A}$ \\
\hline \multicolumn{5}{|l|}{ Six-week stratification } \\
\hline Oklahoma & $55.0 \mathrm{a}$ & $42.4 \mathrm{a}$ & $14.9 \mathrm{a}$ & $3.3 \mathrm{~b}$ \\
\hline Georgia & $31.4 \mathrm{~b}$ & $9.4 \mathrm{~b}$ & $4.9 \mathrm{~b}$ & $5.5 \mathrm{a}$ \\
\hline Delmarva & $14.7 \mathrm{c}$ & $2.0 \mathrm{~b}$ & $2.2 \mathrm{~b}$ & $6.0 \mathrm{a}$ \\
\hline Treatment mean & $34.0 \mathrm{~A}$ & $19.0 \mathrm{~A}$ & $7.6 \mathrm{~A}$ & $4.9 \mathrm{~B}$ \\
\hline
\end{tabular}

Z to Fisher's least significant difference test.

yTreatment means within a column followed by the same uppercase letter are not significantly different at $P \leq 0.05$ according to Fisher's least significant difference test. 
VARIATION AMONG AND WITHIN POPULATIONS. A population $\times$ treatment interaction was found for all parameters $(P \leq 0.0001)$ except germination percentage $(P=0.08)$. Six weeks of stratification caused a greater increase in germination value and peak value for seeds from Oklahoma (increased 5.7 and 4.7 times, respectively), than for seeds from Georgia (increased 4.3 and 3.1 times, respectively) and the Delmarva Peninsula (increased 3.3 and 3.1 times, respectively) (Table 2). Stratification decreased peak day more for seeds from Oklahoma (decreased 3.1 times), than for seeds from Georgia (decreased 1.9 times) and the Delmarva Peninsula (decreased 2.2 times).

Nonstratified seeds from Oklahoma had greater germination percentage, germination value, and peak value than nonstratified seeds from the other two populations, but peak day was not different for seeds from Oklahoma and Georgia (Table 2). All four germination measures for nonstratified seeds from Georgia were intermediate to those of Oklahoma and Delmarva, but different from Delmarva for peak day only (Table 2). After 6 weeks of stratification, seeds from Oklahoma had the highest germination percentage, germination value, and peak value, as well as the lowest peak day. Germination of stratified seeds from Georgia differed from that of seeds from Delmarva for germination percentage only.
Germination varied among individual, half-sibling groups of seed within each population. Means by group for germination percentage ranged from $38 \%$ to $82 \%$ (Oklahoma), $12 \%$ to $58 \%$ (Georgia), and 4\% to 29\% (Delmarva Peninsula) after seeds received 6 weeks of stratification. Eight of the highest 10 germination percentages were for groups from Oklahoma. The highest germinability was shown by stratified seeds from one group from Oklahoma with a germination percentage of $82 \%$, germination value of 89.0, peak value of 22.7, and peak day of 3 . The lowest germinability was shown by nonstratified seeds from one group from the Delmarva Peninsula with a germination percentage of $0.67 \%$, germination value of 0.005 , peak value of 0.056 , and a peak day of 18.

Over all three populations, 6 weeks of stratification increased germination value and peak value, and decreased peak day (Table 2). There was a correlation between the results for nonstratified and stratified seeds. Correlation coefficients and significance levels were $r=0.84, P \leq 0.0001$ for germination percentage; $r=$ $0.80, P \leq 0.0001$ for germination value; $r=0.79$ and $P \leq 0.0001$ for peak value; and $r=0.50, P=0.008$ for peak day.

\section{Growth and morphology of seedlings}

INFLUENCE OF POPULATION AND SEED SOURCE. Growth and

Table 3. Comparisons among seedlings of Alnus maritima from Oklahoma, Georgia, and the Delmarva Peninsula after 18 weeks of growth in a greenhouse. Values are means of observations from six experimental units. Variables describing developmental rates represent the period between 12 and 18 weeks.

\begin{tabular}{|c|c|c|c|}
\hline \multirow{2}{*}{$\begin{array}{l}\text { Dependent } \\
\text { variable }\end{array}$} & \multicolumn{3}{|c|}{ Seedling population } \\
\hline & Oklahoma & Georgia & Delmarva \\
\hline \multicolumn{4}{|l|}{ Stem } \\
\hline Thickness (mm) & $7.4 \mathrm{a}^{\mathrm{z}}$ & $6.9 \mathrm{~b}$ & $6.5 \mathrm{c}$ \\
\hline Curvature rating $^{\mathrm{y}}$ & $1.3 \mathrm{~b}$ & $1.8 \mathrm{a}$ & $1.7 \mathrm{a}$ \\
\hline Deviation from vertical $\left({ }^{\circ}\right)^{x}$ & $5.5 \mathrm{~b}$ & $11.2 \mathrm{a}$ & $13.0 \mathrm{a}$ \\
\hline \multicolumn{4}{|l|}{ Leaf } \\
\hline Length $(\mathrm{cm})$ & $12.8 \mathrm{a}$ & $12.0 \mathrm{~b}$ & $11.6 \mathrm{~b}$ \\
\hline Width (cm) & $6.0 \mathrm{~b}$ & $6.8 \mathrm{a}$ & $6.2 \mathrm{~b}$ \\
\hline Length to width ratio & $2.15 \mathrm{a}$ & $1.76 \mathrm{~b}$ & $1.86 \mathrm{~b}$ \\
\hline Bullate rating ${ }^{\mathrm{w}}$ & $1.3 \mathrm{~b}$ & $1.9 \mathrm{a}$ & $1.9 \mathrm{a}$ \\
\hline Surface area per plant $\left(\mathrm{cm}^{2}\right)$ & $947 \mathrm{a}$ & $732 \mathrm{~b}$ & $667 \mathrm{~b}$ \\
\hline Area ratio $\left(\mathrm{cm}^{2} \cdot \mathrm{g}^{-1}\right)$ & $119 \mathrm{a}$ & $105 \mathrm{~b}$ & $116 \mathrm{a}$ \\
\hline Dry weight per plant (cg) & 339 a & $322 \mathrm{a}$ & $252 \mathrm{~b}$ \\
\hline Specific weight $\left(\mathrm{mg} \cdot \mathrm{cm}^{-2}\right)$ & $3.57 \mathrm{~b}$ & $4.39 \mathrm{a}$ & $3.69 \mathrm{~b}$ \\
\hline \multicolumn{4}{|l|}{ Shoot } \\
\hline Length $(\mathrm{cm})$ & $50.3 \mathrm{~b}$ & $59.4 \mathrm{a}$ & $46.7 \mathrm{~b}$ \\
\hline Internode length (cm) & $3.28 \mathrm{~b}$ & $3.62 \mathrm{a}$ & $3.33 \mathrm{ab}$ \\
\hline Leaves and axillary shoots & $36 \mathrm{a}$ & $27 \mathrm{~b}$ & $28 \mathrm{~b}$ \\
\hline Leaves and shoots per $\mathrm{cm}$ & $0.72 \mathrm{a}$ & $0.46 \mathrm{~b}$ & $0.64 \mathrm{a}$ \\
\hline \multicolumn{4}{|l|}{ Developmental rate } \\
\hline Simple growth $\left(\mathrm{mg} \cdot \mathrm{d}^{-1}\right)$ & $181 \mathrm{a}$ & $160 \mathrm{a}$ & $130 \mathrm{~b}$ \\
\hline Relative growth $\left(\mathrm{mg} \cdot \mathrm{g}^{-1} \cdot \mathrm{d}^{-1}\right)$ & $51.2 \mathrm{a}$ & $45.6 \mathrm{~b}$ & $48.5 \mathrm{ab}$ \\
\hline Net assimilation $\left(\mathrm{mg} \cdot \mathrm{cm}^{-2} \cdot\right.$ week $\left.^{-1}\right)$ & $3.02 \mathrm{a}$ & $3.04 \mathrm{a}$ & $2.94 \mathrm{a}$ \\
\hline \multicolumn{4}{|l|}{ Dry weight } \\
\hline Root (cg) & $292 \mathrm{a}$ & $229 \mathrm{~b}$ & $185 \mathrm{c}$ \\
\hline Shoot (cg) & 568 a & $561 \mathrm{a}$ & $442 \mathrm{~b}$ \\
\hline Total plant (cg) & $860 \mathrm{a}$ & 789 a & $628 \mathrm{~b}$ \\
\hline Root to shoot ratio & $0.52 \mathrm{a}$ & $0.41 \mathrm{~b}$ & $0.42 \mathrm{~b}$ \\
\hline
\end{tabular}

$\overline{{ }^{2} P o p u l a t i o n ~ m e a n s ~ w i t h i n ~ e a c h ~ r o w ~ f o l l o w e d ~ b y ~ t h e ~ s a m e ~ l e t t e r ~ a r e ~ n o t ~ s i g n i f i c a n t l y ~ d i f f e r e n t ~ a t ~} P \leq 0.05$ according to Fisher's least significant difference test.

yPrimary stems were ascribed a curvature rating of 1 if they were uniformly upright or 2 if they were distinctly curved or twisted.

${ }^{\mathrm{x}}$ Overall angle of the primary stem was measured as the deviation from a line perpendicular with the upper plane of the pot.

${ }^{w}$ Leaf condition of each plant was described by assigning a rating of 1 or 2 when $<50 \%$ or $\geq 50 \%$ of the leaves were bullate, respectively. 

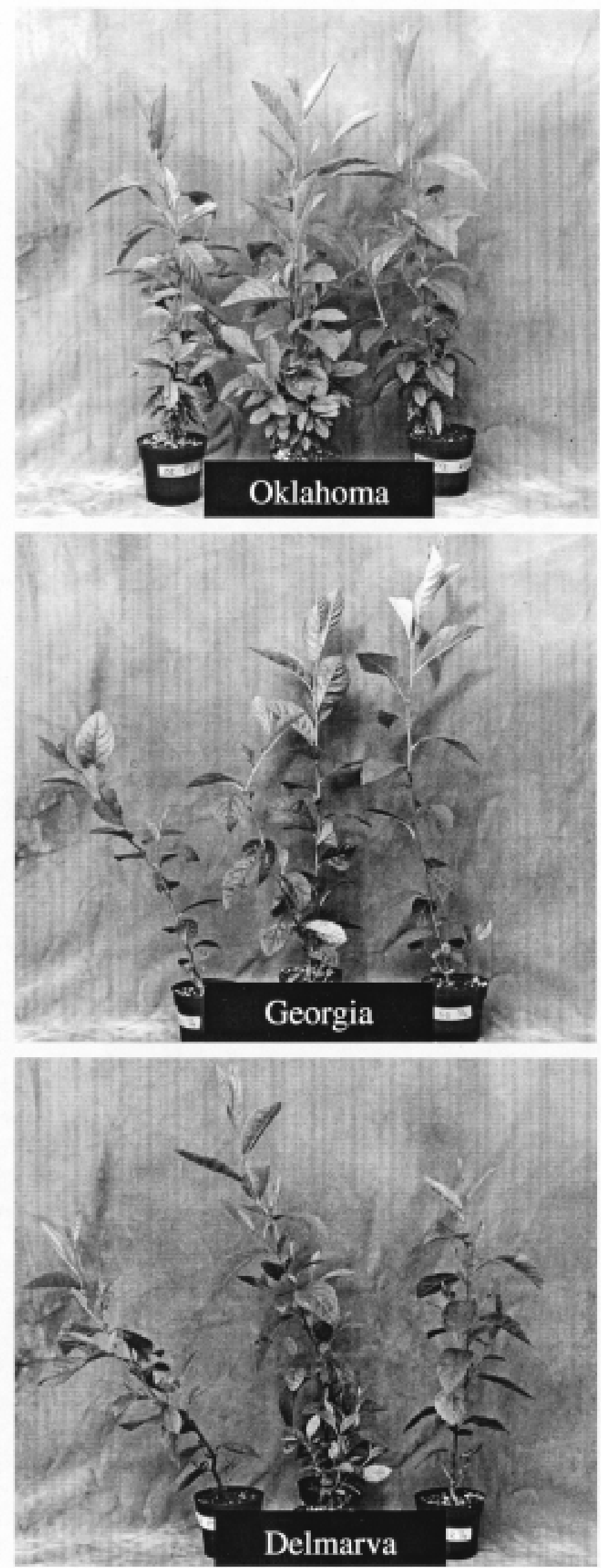

morphology of seedlings varied among populations. Stems of seedlings from Oklahoma were thicker than stems from the other two populations, while stems of seedlings from Delmarva and Georgia had more curvature and deviation from vertical (Table 3, Fig. 1). Leaves of plants from Oklahoma were longer, had a higher ratio of length to width, and had a lower bullate rating than plants from the other two populations (Table 3, Fig. 2).

Shoots of plants from Georgia were 18\% longer than the combined mean length of shoots of plants from the other two populations (Table 3). Seedlings from Georgia also had longer internodes than seedlings from Oklahoma. Seedlings from Oklahoma were densely foliated. They had $23 \%$ more leaves and axillary shoots and $26 \%$ more leaf area than the combined means of the other two populations. Compared to seedlings from Georgia, seedlings from Oklahoma and the Delmarva Peninsula had more leaves and shoots per unit length of primary stem and a higher leaf area ratio (Table 3). Seedlings from Oklahoma and Georgia had higher simple growth rates and leaf, root, shoot, and total dry weights after 18 weeks than seedlings from the Delmarva Peninsula (Table 3). Plants from Oklahoma had a higher root to shoot ratio than plants from the other two populations, while plants from Georgia had the highest specific leaf weight (Table $3)$.

Variation in seedling development within each population was less than variation among populations. For example, total dry weights were not different among half-sibling groups from Oklahoma, and six out of seven and eight out of 10 half-sibling groups from Georgia and Delmarva, respectively, were not different $(P$ $\leq 0.05$ ). Shoot length of seedlings in nine out of 10 half-sibling groups from Oklahoma, six out of seven from Georgia, and eight out of 10 from Delmarva were not different. Six out of ten halfsibling groups from Oklahoma, six out of seven from Georgia, and eight out of ten from Delmarva also had similar numbers of leaves and shoots per unit length of stem.

\section{Discussion}

Stratification increases the rate, uniformity, and completeness of germination (Table 1), findings that will be critical if $A$. maritima is promoted as a new nursery crop produced from seed (Czabator, 1962; Hartmann et al., 1990; Matthews and Powell, 1986). The results for germination value, which is considered the best single measure of quality and germinability of seeds of woody plants (Czabator, 1962; Hartmann et al., 1990), show that 6 to 12 weeks of stratification is best for overcoming embryo dormancy (Table 1). Quadratic models show that 7.4, 9.3,9.6, and 10.0 weeks of stratification optimize germination percentage, germination value, peak value, and germination distribution, respectively. The mean of these values ( 9.1 weeks) may provide the best overall treatment duration for propagating A. maritima from seed. The shorter duration required to optimize germination percentage (7.4 weeks) suggests that although longer stratification periods are efficient for breaking seed dormancy, they can lead to fewer germinated seeds. Because the native range of $A$. maritima is restricted to areas of the United States where winters are relatively short (USDA hardiness zone 7a for Oklahoma and the Delmarva Peninsula; zone $7 \mathrm{~b}$ for Georgia), and seeds are not

Fig. 1. Appearance of 18-week-old seedlings of Alnus maritima from its three disjunct populations. Plants from Oklahoma had less stem curvature, a more upright growth habit, and more leaves and axillary shoots per unit length of stem than plants from Georgia and the Delmarva Peninsula. Pot height $=9.8 \mathrm{~cm}$. 


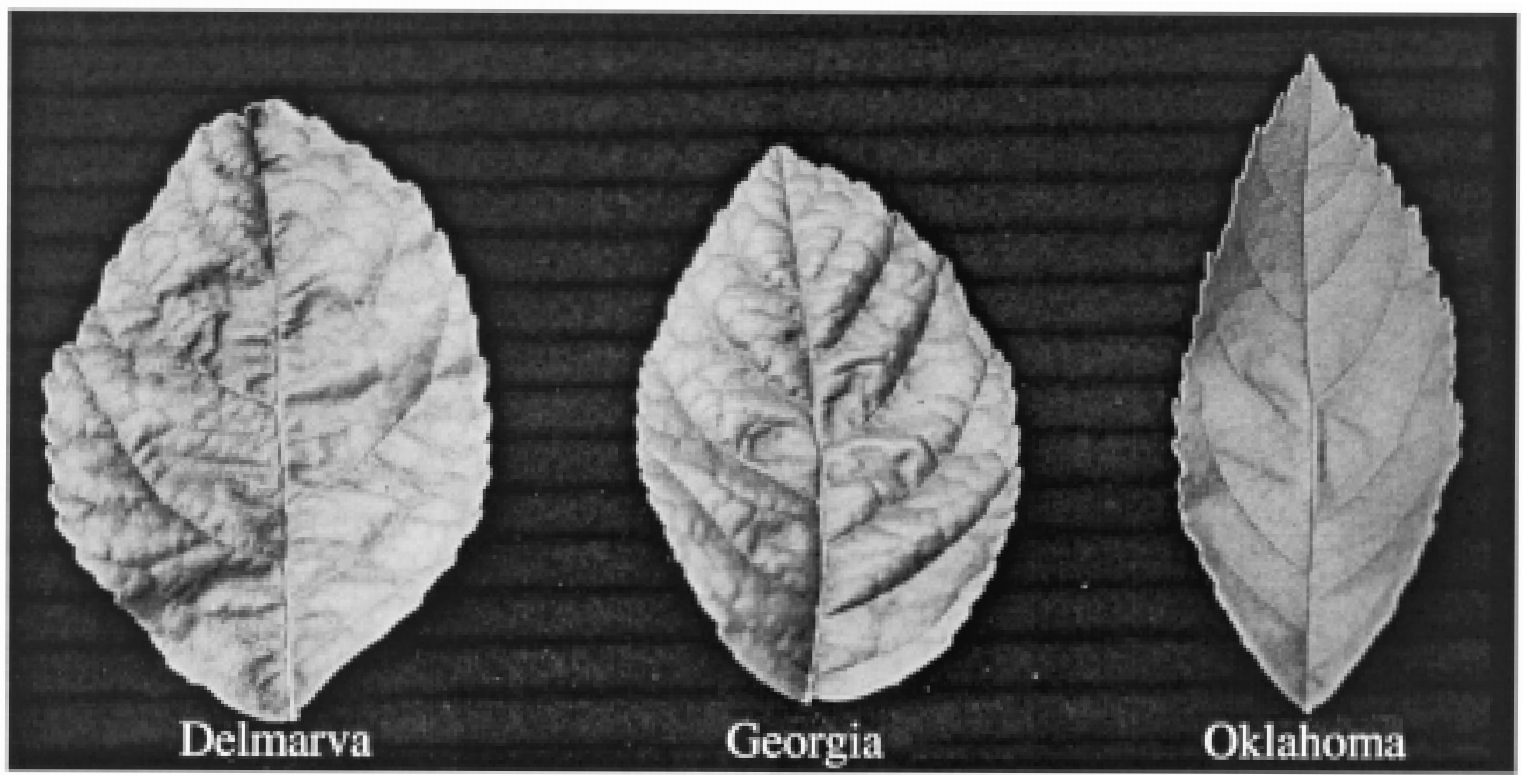

Fig. 2. Morphology of leaf blades removed from seedlings of the three populations of Alnus maritima grown in a common greenhouse environment. Leaves of plants from Oklahoma were longer, more narrow (higher length to width ratio), and exhibited a bullate leaf appearance less frequently than leaves of plants from Georgia and the Delmarva Peninsula.

dispersed until winter (Schrader and Graves, 1999), seeds may be adapted to short periods ( $\approx 6$ to 8 weeks) of chilling $\left(1\right.$ to $10^{\circ} \mathrm{C}$ ), and longer durations may cause seeds to deteriorate. Correlation between results for stratified and nonstratified seeds from the three populations indicates that 6 weeks of stratification increased germination proportional to the germination potential of the seeds from each source and population. This provides evidence that seeds from Georgia and Delmarva do not differ fundamentally from seeds from Oklahoma in their response to cold stratification. Therefore, we conclude that 6 to 10 weeks of cold stratification should be used to overcome seed dormancy and optimize germination of seeds of $A$. maritima.

The distribution of germination percentages (from $4 \%$ to $82 \%$ after stratification for 6 weeks) over the 27 half-sibling groups of seed shows large variation in germinability of seeds from different trees. Within each population, identification of trees that consistently produce high percentages of viable seed of high quality will be important to those interested in producing this species. The difference we observed in germination percentage between the three populations is consistent with a report that seeds from trees on the Delmarva Peninsula germinated at $20 \%$ under conditions similar to those we used (Stibolt, 1978). In our experiment, stratified seeds from the Delmarva Peninsula had the lowest germination percentage $(14.7 \%)$ of the three populations (Table 2). Differences in germinability of seeds indicate divergence in the reproductive potential of the three disjunct populations of A. maritima. If sexual reproduction is the primary means of perpetuating this species in the wild, the population in Oklahoma seems to have a higher natural capacity for survival and range increase. The lower germinability of seeds from Georgia and the Delmarva Peninsula may limit their value for propagation, but use of plants from these populations might lessen concerns about invasiveness. Regardless of seed germinability, A. maritima probably will not be invasive in areas with colder winters than those of its native range because experiments show that stratified seeds fail to germinate after exposure to less than the mean low temperature for USDA zone $7 \mathrm{a}$ for $\geq 3 \mathrm{~d}$ (Schrader and Graves, 1999).

Differences in seed germination and in growth and morphology of seedlings from the three populations of A. maritima provide insights into the ecological adaptations and geographic range of this species. Speculation continues concerning the origin of the disjunct range of $A$. maritima and the relationship between the newly discovered population in Georgia and the populations in Oklahoma and on the Delmarva Peninsula (Furlow, 1979; Schrader, 1999; Stibolt, 1981). Our measurements indicate that phenotypes from Oklahoma were the most divergent. For the 22 traits of growth and morphology reported in Table 3, means for seedlings from Oklahoma were different $(P \leq 0.05)$ from those of the other two populations for 10 traits, while means for seedlings from Georgia and the Delmarva Peninsula were different from the others for seven and six traits, respectively (Table 3 ). Contrasts of the populations individually show that plants from Oklahoma differed from plants from Georgia for 17 traits and from plants from the Delmarva Peninsula for 14 traits; plants from Georgia and the Delmarva Peninsula differed for only 11 of the 22 traits. In addition, the second germination experiment showed seven differences in germinability measures between seeds from Oklahoma and those of the other two populations but only two differences between seeds from Georgia and the Delmarva Peninsula (Table 2). Collectively, these data provide initial phenotypic evidence that the newly discovered population of A. maritima in Georgia more closely resembles the population on the Delmarva Peninsula than it does the population in Oklahoma. If the small population in Georgia was introduced from one of the two larger populations, the population from the Delmarva Peninsula was the more likely progenitor. If the three known populations resulted from the reduction of a larger range, the western population, now restricted to Oklahoma, may have been isolated from the eastern populations earlier than the Georgia and Delmarva populations were isolated from each other.

Knowledge of differences in the growth and morphology of plants from the three populations should be helpful for selecting genotypes with superior horticultural traits. The higher root dry weights and root to shoot ratios (Table 3) of plants from Oklahoma may be an adaptation to the fast-moving streams and rivers 
where these plants occur. Extensive root systems may secure plants, and the soil around them, under erosive conditions. Plants from Georgia and the Delmarva Peninsula, where populations of A. maritima occur along slow-moving or stagnant waterways (Schrader, 1999; Schrader and Graves, 1999; Stibolt, 1981), developed relatively small root systems (Table 3). The larger root systems of plants from Oklahoma might also be an adaptation to periodic drought. The water levels of streams and rivers in Oklahoma vary throughout the growth season, and extensive root systems might sustain plants from Oklahoma if or when the waterways become dry. The more densely foliated genotypes from Oklahoma, which had greater leaf surface areas and more leaves and axillary shoots than other plants (Table 3, Fig. 1), may be well suited for use as a large shrub or hedge. Plants from Georgia, with greater shoot and internode lengths and fewer leaves and axillary shoots (Table 3 ), may be particularly easy to train as single-trunked trees. The curvature and deviation from vertical of plants from Georgia and the Delmarva Peninsula (Table 3, Fig. 1) suggest they may develop an irregular form as they are cultured in a nursery, but the higher rate of growth, and resulting high dry weight of plants from Oklahoma and Georgia (Table 3), indicate that seedlings from these populations could reach marketable size sooner than would plants from the Delmarva Peninsula. The bullate leaves of seedlings from Georgia and Delmarva, and the narrower leaves of seedlings from Oklahoma (Fig. 2), also characteristic of mature plants from this population (Stibolt, 1978), represent traits upon which selections might be based. Further research is needed to assess the long-term stability and value of these developmental and morphological traits under conditions typical of commercial nursery production and managed landscapes.

\section{Literature Cited}

Benson, D.R. and W.B. Sylvester. 1993. Biology of Frankia strains, actinomycete symbionts of actinorhizal plants. Microbiol. Rev. 57:293319.

Bewley, J.D. and M. Black. 1994. Seeds: Physiology of development and germination. 2nd ed. Plenum Press, New York.

Czabator, F.J. 1962. Germination value: An index combining speed and completeness of pine seed germination. For. Sci. 8:386-396.

Dirr, M.A. and C.W. Heuser, Jr. 1987. The reference manual of woody plant propagation: From seed to tissue culture. Varsity Press, Athens, Ga.

Furlow, J.J. 1979. The systematics of the American species of Alnus (Betulaceae). Rhodora 81:1-121, 151-248.

Harper, J.L. 1977. Population biology of plants. Academic Press, New York.

Hartmann, H.T., D.E. Kester, and F.T. Davies, Jr. 1990. Plant propagation: Principles and practices. 5th ed. Prentice Hall, Englewood Cliffs, N.J.

Hennessey, T.C., L.K. Bair, and R.W. McNew. 1985. Variation in response among three Alnus spp. clones to progressive water stress. Plant Soil 87:135-141.

International Seed Testing Association. 1985. International rules for seed testing: Rules 1985. Seed Sci. Technol. 13:299-355.

Matthews, S. and A.A. Powell. 1986. Environmental and physiological constraints on field performance of seeds. HortScience 21:1125-1128.

Mazzeo, P. 1986. Alnus maritima. Amer. Nurseryman 163(11):146.

SAS Institute Inc. 1988. SAS/STAT user's guide. Release 6.03 ed. SAS Inst. Inc., Cary, N.C.

Schrader, J.A. 1999. Propagation of Alnus maritima from its three disjunct populations. MS thesis, Iowa State Univ., Ames.

Schrader, J.A. and W.R. Graves. 1999. Timing of seed dispersal may limit the reproductive success of Alnus maritima. Castanea (in press).

Stibolt, V.M. 1978. The ecology and systematics of Alnus maritima Muhl. ex Nutt. (Betulaceae). MS thesis, Univ. of Maryland, College Park.

Stibolt, V.M. 1981. The distribution of Alnus maritima Muhl. ex Nutt. (Betulaceae). Castanea 46:195-200. 